\title{
Erratum to JEMS (Journal of ETA Maritime Science), Volume 4, Issue 2 (2016)
}

Erratum (ER)

DOI ID: 10.5505/jems.2016.21043

The article that DOI ID is 10.5505/jems.2016.78942 has an oversight about reference numbering;

Şekil 2. Yakıt Pompası Çıkışındaki Basınç ve Enjektör İğnesinin Kalkma Miktarının Krank Açısına Göre Değişimi [9]

The correct reference list is given below.

[1] Gay R.R., Palmer, C.A. and Erbes M.R. (2004). Power Plant Performance Monitoring. R-squared Publishing.

[2] Varbanets, R.A. and Karianskiy, S.A. (2012). Analyse of Marine Diesel Engine Performance. Journal of Polish CIMAC Energetic Aspects, 7(1):269-275.

[3] Lamaris, V.T. and Hountalas D.T. (2010). A general purpose diagnostic technique for marine diesel engines - Application on the main propulsion and auxiliary diesel units of a marine vessel. Energy Conversion and Management, 51:740-753.

[4] Hountalas, D.T., Papagiannakis, R.G., Zovanos, G., Antonopoulos, A. (2014). Comparative evaluation of various methodologies to account for the effect of load variation during cylinder pressure measurement of large scale two-stroke diesel engines. Applied Energy, 113:1027-1042.

[5] Kowalski, J. (2014). An experimental study of emission and combustion characteristics of marine diesel engine with fuel pump malfunctions. Applied Thermal Engineering, 65:469-476.

[6] Basurko, O.C. and Uriondo, Z. (2015). Condition-Based Maintenance for medium speed diesel engines used in vessels in operation. Applied Thermal Engineering, 80:404-412.

[7] Zhang, K., Wang, X., Kong, X., Zeng, H., Lao, X. (2014). Thermal Management System Analysis of Marine Diesel Engine. Journal of Automation and Control Engineering, 2(1):75-78.

[8] Cong Guan, C., Theotokatos, G. and Chen, H. (2015). Analysis of Two Stroke Marine Diesel Engine Operation Including Turbocharger Cut-Out by Using a Zero-Dimensional Model. Energies, 8:5738-5764

[9] Kegl, B., Kegl, M., Pehan, S. (2013). Green Diesel Engines. Springer-Verlag London.

[10] Littlefuse Selco EngineEye (E5000). (2014). PC software User's Manual. Version 1.0.4.6.

[11] Zhao Z., Zhang F., Huang Y., Zhao C. (2014). Determination of TDC in a hydraulic free-piston engine by a novel approach. Applied Thermal Engineering, 70:524-530.

[12] Pipitone E., Beccari A. (2010). Determination of TDC in internal combustion engines by a newly developed thermodynamic approach. Applied Thermal Engineering, 30:1914-1926.

[13] Pipitone E., Beccari A., Beccari S. (2007). The Experimental Validation of a New Thermodynamic Method for TDC Determination. SAE Paper:2007-24-0052.

[14] Miao R., Li J., Shi L., Deng K. (2013). Study of Top Dead Center Measurement and Correction Method in a Diesel Engine, Research Journal of Applied Sciences, Engineering and Technology, 6(6):1101-1105.

[15] ISO 3046-1:2002 (2008). Reciprocating internal combustion engines-Performance, Part 1: Declarations of power, fuel and lubricating oil consumptions, and test methods - Additional requirements for engines for general use.

The editorial board of JEMS apologizes for any inconvenience that may result from this oversight. 